\title{
Perencanaan Produksi dan Pengendalian Persediaan pada Perusahaan Manufaktur
}

Myra Beatrice Soeltanong1, Catur Sasongko ${ }^{2}$

1 Universitas Indonesia, Depok, Indonesia

¿Universitas Indonesia, Depok, Indonesia

\section{ARTICLE INFO \\ JEL Classification: \\ M11, L23}

Key words:

manufacturing, production planning, inventory control.

\begin{abstract}
This research was conducted with the aim of observing the production planning process applied by PT X then designing a comprehensive production planning and inventory control so that it can overcome the occurrence of shortages and excess of inventory in the company. The research was conducted by observing a springbed manufacturing company PT X in Makassar. The data used are primary and secondary data, using instruments such as interviews, conducted on staffs and management of PT X, site visits, as well as company historical data. The results of the research were in the form of production planning, through demand forecasting, master production schedule, and planning for resource requirements. In addition, the researcher also established an inventory control system that could support the company's production process using the EOQ method, safety stock, and reorder points. The results of the research are not necessarily applicable to other companies with different demand patterns or to companies with different industries. In addition, the methods used in production planning and inventory control are limited in this study.
\end{abstract}

\begin{abstract}
ABSTRAK
Penelitian ini dilakukan dengan tujuan untuk mengamati proses perencanaan produksi yang diterapkan perusahaan manufaktur PT X, merancang perencanaan produksi dan pengendalian persediaan yang komprehensif sehingga dapat mengatasi terjadinya kekurangan maupun kelebihan persediaan pada perusahaan. Penelitian dilakukan dengan melakukan observasi pada perusahaan manufaktur PT X, perusahaan manufaktur yang memproduksi kasur per di kota Makassar. Data yang digunakan merupakan data primer dan sekunder, berupa wawancara yang dilakukan pada jajaran staf dan manajemen PT X, serta data historis perusahaan. Hasil penelitian berupa perencanaan produksi yang melewati tahap peramalan permintaan, pembentukan jadwal induk produksi, serta perencanaan kebutuhan sumber daya. Selain itu, peneliti juga membentuk sistem pengendalian persediaan yang dapat mendukung kelancaran proses produksi perusahaan dengan metode Economic Order Quantity (EOQ), persediaan pengaman, dan titik pemesanan kembali. Hasil penelitian belum tentu dapat diterapkan pada perusahaan lain dengan pola permintaan maupun pada perusahaan dengan industri yang berbeda. Selain itu, metode yang digunakan dalam pembentukan perencanaan produksi dan pengendalian persediaan pun menjadi keterbatasan dalam penelitian ini.
\end{abstract}

\section{PENDAHULUAN}

Persaingan usaha dalam sepuluh tahun terakhir mengalami peningkatan yang signifikan. Hal ini didukung dengan adanya kemajuan teknologi dan sistem informasi. Kompetisi yang dihadapi oleh perusahaan tidak lagi berfokus pada harga barang yang rendah namun juga pada nilai tambah yang dapat diberikan kepada para pelanggan. Agar dapat bertahan di pasar diperlukan adanya keunggulan bersaing dalam suatu perusahaan. Sebuah perusahaan dikatakan memiliki keunggulan bersaing apabila perusahaan tersebut dapat menawarkan produk atau layanan pada pelanggan dengan mutu yang sama atau lebih tinggi, namun dengan biaya yang lebih rendah dibandingkan para pesaingnya (Thompson et al., 2018). Selain

\footnotetext{
${ }^{*}$ E-mail korespondensi: ${ }^{1}$ myrabeatrices@gmail.com
} 
keunggulan bersaing, perusahaan juga harus memberikan nilai tambah bagi para pelanggan agar dapat bertahan di pasar (Chan \& Prakash, 2012). Salah satu faktor yang berperan penting bagi para pelanggan dalam memilih produk adalah harga. Perusahaan seyogyanya tidak hanya berfokus pada harga yang rendah namun juga diimbangi dengan adanya efisiensi biaya sehingga memberikan hasil yang positif bagi kinerja perusahaan dalam perspektif keuangan.

Suatu produk barang jadi tentu harus melewati proses produksi, dimana bahan baku diolah kemudian diproses hingga menjadi barang jadi. Apabila suatu produk dapat diproduksi dengan biaya yang rendah maka produsen dapat menyesuaikan harga jual dengan lebih fleksibel dan mampu bersaing di pasar. Biaya produksi yang rendah memberikan ruang bagi produsen untuk memasarkan produknya pada harga yang rendah. Salah satu strategi bisnis yang sering digunakan perusahaan adalah dengan menerapkan strategi biaya rendah (Thompson et al., 2018). Strategi ini dapat membantu perusahaan memperoleh keunggulan bersaing di pasar. Sebagai upaya untuk mengoptimalkan efisiensi produksi diperlukan perencanaan yang komprehensif.

Permasalahan yang sering ditemukan pada perusahaan manufaktur, khususnya yang skalanya kecil dan menengah, adalah perencanaan produksi yang tidak efisien dikarenakan kurangnya kemampuan sumber daya manusia dalam menerapkan perencanaan tersebut (Akande, 2019). Perencanaan membantu suatu entitas untuk mencapai tujuan entitas dan mengarahkan perilaku serta memberikan standar yang dapat mengendalikan kegiatan kelompok maupun individu dalam entitas untuk mencapai tujuan perusahaan (Flamholz et al., 1985). Perencanaan produksi merupakan bagian dari manajemen operasi, salah satu ilmu yang paling dibutuhkan dalam industri manufaktur. Dengan memiliki keahlian dalam bidang tersebut, perusahaan dapat menjadi lebih kompetitif. Hal ini diperlukan tiap entitas menimbang bahwa hambatan masuk ke suatu pasar makin kecil. Kompetitor baru yang tidak memiliki pengalaman sebelumnya dapat dengan mudah memasuki pasar karena memiliki akses pada sumber dana yang besar (Fajar \& Lestari, 2017).

Perencanaan produksi harus diiringi dengan manajemen persediaan yang baik (Kumar \& Suresh, 2008). Jumlah persediaan harus selalu memadai agar tidak menghambat laju produksi sehingga perusahaan dapat selalu memenuhi permintaan pelanggan.

PT X merupakan perusahaan manufaktur di kota Makassar, Sulawesi Selatan, yang telah berdiri sejak tahun 1996. Produk yang diproduksi berupa berbagai jenis kasur per (spring bed), kasur busa, divan, maupun sandaran. Kapasitas produksi dapat mencapai 5.000 - 7.000 kasur dalam sebulan. PT X melayani penjualan baik kepada pengguna akhir maupun pada distributor. Dalam wawancara awal dengan direktur PT X pada tanggal 20 November 2019, ditemukan permasalahan produksi yang terjadi tiap tahun antara lain terdapat kelebihan maupun kekurangan persediaan pada periode tertentu. Perusahaan memberikan program promosi yang berbeda tiap tahun, misalnya berupa diskon maupun cashback. Pada periode inilah biasanya terjadi kekurangan persediaan yang disebabkan oleh kenaikan permintaan yang cukup drastis. Hal ini akan diikuti oleh kelebihan persediaan yang sering terjadi pada saat periode promosi telah selesai. Kelebihan ini menyebabkan tingkat persediaan terkadang melampaui kapasitas penyimpanan perusahaan. Stok bahan baku maupun barang jadi yang melampaui kapasitas atau tidak maksimal akan menggunakan lahan untuk penyimpanan.

Jumlah permintaan yang fluktuatif menyebabkan terjadinya kelebihan atau kekurangan persediaan. Permasalahan ini terjadi karena tidak adanya perencanaan produksi yang tepat dan komprehensif yang dijalankan oleh bagian produksi sehingga sumber daya dan kapasitas produksi tidak berjalan secara maksimal. Perencanaan produksi dilakukan secara subjektif dan diserahkan pada bagian produksi. Terdapat 
beberapa produk yang telah diproduksi dalam jumlah banyak namun tidak terjual dalam waktu yang cukup panjang. Di samping itu, pihak manajemen belum melakukan inisiasi untuk menerapkan perencanaan produksi pada PT X. Hal yang menjadi hambatan dalam penerapan ini adalah kurangnya keahlian sumber daya manusia yang dapat membentuk perencanaan produksi serta manajemen persediaan secara komprehensif.

Perusahaan manufaktur perabot memiliki karakter antara lain: memiliki siklus produksi yang panjang dan memiliki produk yang kompleks, dengan bahan baku yang berukuran besar (Chinguwa, Madanhire, \& Musoma, 2013). Perencanaan produksi dapat membantu perusahaan dalam menjalankan proses produksi dengan memberikan gambaran alur dan alokasi produksi perusahaan. PT $X$ memproduksi 268 produk yang terdiri dari 21 jenis kasur dan 5 jenis divan, masing-masing dengan enam pilihan ukuran, serta 28 jenis sandaran dengan tiga hingga enam pilihan ukuran. Selain itu, PT X juga menerima pemesanan dengan ukuran khusus sesuai dengan permintaan pelanggan. Penelitian ini berfokus pada perencanaan produksi produk AMS, yaitu produk yang mendominasi $40 \%$ hingga 50\% kegiatan produksi dan penjualan perusahaan.

\section{TELAAH TEORI DAN PENGEMBANGAN HIPOTESIS}

\subsection{PERENCANAAN PRODUKSI}

Produksi merupakan salah satu fungsi bisnis dalam suatu perusahaan, yang berhubungan dengan perubahan bentuk dari input menjadi output dengan kualitas tertentu, sehingga produksi dapat dikategorikan sebagai proses penambahan nilai yang terdapat dalam setiap tahap produksi (Kumar \& Suresh, 2008). Sebagai upaya untuk meningkatkan persaingan di industri manufaktur dibutuhkan suatu alat maupun sistem untuk mengatur aktivitas produksi untuk memaksimalkan sumber daya perusahaan. Dalam beberapa industri, khususnya manufaktur, manajemen operasi memiliki peranan yang penting (Fajar \& Lestari, 2017). Manajemen operasi yang buruk dapat memberikan dampak negatif terhadap perusahaan, misalnya kenaikan biaya, waktu maupun tenaga, hingga kekurangan persediaan. Perencanaan produksi merupakan salah satu bentuk dari manajemen operasi, yang merupakan suatu alat yang dapat digunakan perusahaan untuk mengarahkan sistem produksi dengan perencanaan serta sistem kontrol yang komprehensif. Perencanaan produksi dan pengendalian persediaan dibutuhkan perusahaan agar perusahaan tersebut dapat menggunakan sumber daya secara efektif, dari segi jumlah yang digunakan, maupun waktu yang digunakan untuk melakukan proses produksi.

Perencanaan produksi diharapkan bersifat realistis dan dapat diterapkan (Bonney, 2000). Perencana produksi harus terlebih dahulu mengetahui kapasitas perusahaan untuk menerapkan perencanaan produksi agar dapat berjalan dengan efektif serta dapat mencapai tujuan produksi, baik dari segi kualitas, kuantitas, maupun biaya. Selain itu, perencanaan produksi juga membantu perusahaan membentuk dan menjalankan alur produksi dengan lancar dengan tujuan untuk memenuhi permintaan pelanggan dengan memperhatikan kualitas dan waktu pengantaran yang tepat.

Suatu sistem perencanaan produksi yang baik hendaknya dapat memberikan informasi mengenai barang apa yang akan diproduksi, apa saja yang dibutuhkan dalam proses produksi, misalnya kapasitas sumber daya, apa yang dimiliki perusahaan, serta apa yang dibutuhkan perusahaan dalam upaya memproduksi barang tersebut (Arnold, Chapman, \& Clive, 2008). Poin-poin tersebut mengarahkan pihak manajemen produksi untuk memperhatikan jumlah produk yang harus diproduksi dalam tiap periode, tingkat persediaan yang diinginkan, serta ketersediaan sumber daya yang dibutuhkan perusahaan.

Perencanaan produksi suatu perusahaan dibentuk berdasarkan peramalan permintaan yang mengacu pada data historis perusahaan. Peramalan (forecast) dibutuhkan tidak hanya dalam perencanaan produksi, namun juga dalam proses pengambilan keputusan 
perusahaan, misalnya manajemen persediaan, pengembangan produk, perencanaan proses produksi dan rantai pasok, dan sebagainya (Kalchschmidt, Verganti, \& Zotteri, 2006), yang diperlukan untuk mendukung keputusan dalam produksi dan persediaan barang baik dalam jangka waktu panjang maupun pendek (Fildes \& Beard, 1992). Dengan adanya peramalan dan perencanaan yang baik, perusahaan akan mampu memberikan layanan yang maksimal dan memaksimalkan tingkat efisiensi produksi dalam perusahaan (Fajar \& Lestari, 2017). Peramalan permintaan merupakan informasi yang akan dijadikan dasar perencaan produksi, penjadwalan induk produksi, perencanaan kebutuhan sumber daya, serta pengendalian persediaan. Peramalan permintaan dapat dijadikan alat bantu pihak manajemen dalam mengawasi tingkat produksi perusahaan

Metode peramalan yang digunakan dalam penelitian ini adalah metode moving average. Metode ini merupakan salah satu metode yang umum digunakan dalam membentuk proyeksi permintaan, dengan cara menghitung rata-rata nilai dari data historis kemudia digunakan untuk memperkirakan nilai pada periode berikutnya (Lehaney, Mason, \& Lind, 2017), yang dapat dirumuskan sebagai berikut:

dimana

$$
M A=\frac{\left(n_{1}+n_{2}+n_{3}+\cdots\right)}{N}
$$

$$
\begin{array}{ll}
\text { MA } & =\text { Moving Average } \\
\text { N1 } & =\text { Data periode } 1 \\
\text { N2 } & =\text { Data periode } 2 \\
\text { N3 } & =\text { Data periode } 3 \\
\text { N } & =\text { Jumlah periode moving average }
\end{array}
$$

Jadwal induk produksi dibentuk berdasarkan perencanaan produksi sehingga jumlah produk pada jadwal induk produksi harus sama dengan jumlah produk dalam perencanaan produksi. Informasi yang dibutuhkan untuk membentuk sebuah jadwal induk produksi dapat diperoleh melalui perencanaan produksi, peramalan permintaan barang jadi, pesanan aktual yang diperoleh dari pelanggan, tingkat persediaan barang jadi, serta kapasitas produksi perusahaan. Langkah dalam melakukan penjadwalan induk produksi adalah sebagai berikut (Lu et al., 2013):

a. Menghitung jumlah atau kuantitas kebutuhan awal, yaitu jumlah pesanan penjualan.

b. Menghitung jumlah persediaan yang tersedia.

c. Menghitung kebutuhan dalam periode tertentu kemudian tentukan jumlah output yang direncanakan. Hitung jumlah stok yang tersedia untuk periode berikutnya setelah dikurangi stok untuk memproduksi output yang direncanakan, dan seterusnya.

d. Menghitung jumlah input yang direncanakan yang disesuaikan dengan lead time, Overall Equipment Effectiveness (OEE), dan jumlah output yang direncanakan.

OEE merupakan salah satu alat yang dapat digunakan dalam mengukur tingkat efektivitas kegiatan operasional perusahaan manufaktur (Stamatis, 2010). OEE memecah kinerja unit manufaktur menjadi tiga komponen terpisah yang dapat diukur: Ketersediaan (Availability), Kinerja (Performance), dan Kualitas (Quality).

\section{OEE $=$ Availability $\times$ Performance $\times$ Quality}

Komponen Availability merupakan perbandingan antara waktu operasional mesin secara keseluruhan dan waktu operasional mesin yang terganggu akibat masalah teknis kerusakan mesin maupun waktu untuk menyesuaikan apabila terdapat perubahan aturan pada mesin dalam kegiatan operasional sehari-hari, yang dapat dihitung sebagai berikut:

Availability $=$

jam kerja mesin - (kerusakan mesin + pengaturan) jam kerja mesin

Komponen Performance menggambarkan tingkat efektivitas mesin dengan mempertimbangkan adanya gangguan mesin akibat kesalahan operator mesin dan kecepatan operator dalam mengoperasikan mesin tersebut, yang dapat dihitung sebagai berikut: 


$$
\text { Performance }=\frac{\text { jumlah unit yang diproduksi }}{\text { waktu yang tersedia } \times \text { cycle time }}
$$

Sedangkan komponen Quality pada OEE menggambarkan kualitas produk yang dihasilkan tiap mesin dengan membandingkan total produk yang diproduksi dengan produk cacat:

\section{Quality}

$=\frac{\text { Jumlah unit yang diproduksi }- \text { unit layak jual }}{\text { jumlah unit yang diproduksi }}$

Penjadwalan induk produksi merupakan salah satu alat perencanaan yang baik yang dapat menghubungkan antara bagian penjualan dan bagian produksi. Pada tahap selanjutnya, penjadwalan induk produksi akan menyediakan informasi yang dibutuhkan untuk membentuk perencanaan kebutuhan sumber daya, misalnya komponen apa yang dibutuhkan, dari mana komponen tersebut dapat diperoleh, dan sebagainya. Penjadwalan induk produksi bertujuan untuk mempertahankan pelayanan yang baik pada pelanggan dengan cara menjadwalkan produksi agar dapat memenuhi permintaan, serta memanfaatkan bahan baku, tenaga, dan sumber daya lain dengan sebaik-baiknya. Penjadwalan induk produksi juga bertujuan untuk mempertahankan persediaan agar tetap berada pada tingkat yang diperlukan.

\subsection{Pengendalian PersediaAn}

Pengendalian persediaan menitikberatkan fokus pada penyimpanan serta penggunaan persediaan agar persediaan tetap berada dalam jumlah yang memadai kapanpun diperlukan untuk menghasilkan nilai ekonomi yang maksimum. Tujuan dari pengendalian persediaan adalah untuk meminimalisir kemungkinan adanya gangguan dalam jadwal produksi serta menjaga agar investasi modal dalam bentuk persediaan tidak berlebihan. Kontrol persediaan berfokus pada tiga topik, antara lain jumlah pemesanan barang, interval pemesanan, serta sistem kontrol persediaan (Zomerdijk \& Vries, 2003). Topik-topik ini menjawab barang apa yang harus dipesan, berapa jumlah barang yang seharusnya dipesan, dengan memperhitungkan biaya pemesanan barang tersebut, serta kapan barang tersebut harus dipesan agar tidak mengganggu produksi dan penjualan.

Pengendalian persediaan dapat dilakukan dengan beberapa metode yang berbeda-beda tiap perusahaan, disesuaikan dengan kondisi perusahaan pada periode tertentu (Barwa, 2015). Metode yang umum digunakan misalya dengan menentukan tingkat Economic Order Quantity (EOQ), Persediaan Pengaman, serta Titik Pemesanan Kembali. Economic Order Quantity (EOQ) adalah jumlah pemesanan optimal yang meminimalisir biaya pemesanan dan penyimpanan (Sporta, 2018). Persediaan pengaman merupakan jumlah rata-rata persediaan yang disimpan yang dapat memenuhi ketidakpastian penawaran dan permintaan dalam jangka pendek (Silver, Pyke, \& Peterson, 2016). Adanya persediaan pengaman memungkinkan perusahaan untuk mengatasi apabila perusahaan mengalami kehabisan persediaan (Shenoy \& Rosas, 2018). Tingkat persediaan pengaman harus mencapai tingkat tertentu yang bisa digunakan selama proses pengiriman barang dan cukup untuk memenuhi permintaan, namun tidak menyebabkan biaya penyimpanan yang tinggi. Titik pemesanan kembali merupakan salah satu metode kontrol persediaan yang menentukan jumlah minimum persediaan untuk dipesan kembali (Barwa, 2015).

Sistem pengendalian persediaan yang baik memiliki tujuan bukan untuk meminimalkan persediaan namun untuk menyeimbangkan persediaan agar tidak berlebihan maupun kekurangan. Jumlah persediaan yang berlebih dapat menyebabkan biaya meningkat sehingga mengurangi keuntungan perusahaan, kerusakan barang, dan keusangan (Gimenez \& Ventura, 2005). Menentukan tingkat persediaan yang tepat bagi sebuah perusahaan merupakan salah satu tantangan yang besar yang dihadapi oleh pihak manajemen (Rădăşanu, 2016). Pasalnya, apabila perusahaan memiliki tingkat persediaan yang terlalu tinggi maupun terlalu rendah, maka akan menyebabkan meningkatnya biaya atas persediaan tersebut. 
Tujuan utama dilakukannya pengendalian persediaan adalah untuk meningkatkan pelayanan pelanggan sehingga perusahaan dapat mengembangkan pangsa pasar melalui pelayanan yang baik.

\section{METODE PENELITIAN}

Penelitian dilakukan pada PT X yang beroperasi di kota Makassar, Sulawesi Selatan. Proses penelitian dimulai terhitung sejak wawancara awal yaitu tanggal 20 November 2019, dilanjutkan dengan tahap pengumpulan data, wawancara lanjutan, hingga analisis data dan penyampaian hasil penelitian. PT $X$ merupakan sebuah perusahaan manufaktur yang bergerak di bidang produksi kasur per.

Penelitian dilakukan dengan instrumen penelitian berupa wawancara semi-terstruktur. Peneliti dapat mengeksplor lebih dalam mengenai fenomena yang ingin digali melalui pertanyaan yang ingin diberikan kepada pihak yang di wawancara. Wawancara semiterstruktur merupakan metode wawancara dimana pewawancara sebelumnya telah menyiapkan pertanyaan yang terstruktur, yang dijadikan pedoman pertanyaan lanjutan dalam melakukan wawancara (Bastian, Winardi, \& Fatmawati, 2018). Wawancara ini dilakukan dengan tujuan mendapatkan perspektif lebih luas dari pihak peserta wawancara.

Wawancara semi-terstruktur dilakukan sebanyak 6 kali sejak wawancara awal tanggal 20 November 2019 dengan 4 jajaran direksi perusahaan, yaitu dengan ibu BD selaku Direktur Keuangan; ibu LL selaku Direktur Marketing, Human Resource dan General Affair, Bapak AT selaku Direktur Produksi; serta bapak DD selaku Direktur Purchasing. Data yang diperoleh berupa informasi mengenai proses bisnis perusahaan, alur produksi, serta informasi lainnya terkait aktivitas produksi perusahaan. Selain itu, wawancara dilakukan dengan Kepala Bagian Gudang, Bapak YD dan Kepala Bagian Produksi, Bapak JM.

Berdasarkan wawancara awal dengan pihak manajemen PT X yang dilakukan pada tanggal 20 November 2019, yang kemudian divalidasi oleh data historis perusahaan, produk AMS merupakan produk yang mendominasi penjualan yaitu sekitar 45 hingga 60 persen. PT $X$ telah menjalankan sistem perencanaan produksi dengan metode subjektif, yaitu metode yang berdasarkan pengetahuan, pengalaman, serta penilaian individu atau pihak tertentu.

Penelitian ini dilakukan dengan tahap awal yaitu identifikasi masalah. Permasalahan yang terjadi pada PT $\mathrm{X}$ bersumber dari tidak adanya perencanaan produksi serta manajemen persediaan yang baik. Sebagai upaya untuk mengevaluasi serta memberikan solusi pada PT X, maka pendekatan yang digunakan adalah dengan studi kasus dimana dilakukan penelitian mendalam mengenai permasalah tersebut agar melalui penelitian ini dapat dihasilkan sebuan rancangan perencanaan produksi dan manajemen persediaan yang dapat diimplementasikan pada PT $X$. Selanjutnya, dilakukan pengumpulan data yang dilakukan melalui observasi di perusahaan khususnya pada bagian keuangan dan produksi. Proses wawancara dan observasi dilakukan pada staf dan manajemen untuk mengetahui proses bisnis dan kendala yang dihadapi perusahaan.

\section{HASIL DAN PEMBAHASAN}

Pihak manajemen PT $X$ telah menerapkan sistem perencanaan produksi secara subjektif selama lebih dari 10 tahun, sejak awal perusahaan didirikan. Hal ini berarti bahwa sistem perencanaan yang telah dibentuk oleh pihak manajemen sangat bergantung pada kemampuan dan pengalaman pihak manajemen secara individual dalam menghadapi perubahan pasar. Sistem yang telah berjalan selama lebih dari 10 tahun ini didukung dengan jajaran manajemen yang telah menempati posisi masing-masing sejak awal berdirinya perusahaan. Jajaran direksi perusahaan menempati posisi tetap dan memiliki wewenang dalam membuat keputusan penting bagi perusahaan, sehingga keputusan maupun sistem produksi yang diterapkan didasari oleh kemampuan yang diperoleh dari pengetahuan dan pengalaman pihak manajemen dalam pengambilan keputusan. 
PT X telah beberapa kali menghadapi kendala pada bagian produksi dan persediaan, terutama saat terjadi lonjakan permintaan pada periode tertentu. Pihak manajemen dapat mengatasi kendala tersebut dengan cara menambah tenaga kerja harian, maupun dengan pekerja lembur. Solusi yang diberikan pihak manajemen dapat mengatasi permasalahan dengan cepat namun memiliki risiko tertentu pada perusahaan. Risiko yang dapat terjadi misalnya kualitas kerja tenaga harian yang tidak memenuhi standar, biaya tambahan untuk pelatihan tenaga kerja harian, serta biaya tambahan yang diperlukan untuk upah lembur tenaga kerja. Dampak terhadap perusahaan yang terjadi adalah meningkatnya biaya produksi sehingga mempengaruhi tingkat kepuasan pelanggan dan laba perusahaan secara keseluruhan.

Seperti pada perusahaan umumnya, PT X pun mengalami fluktuasi pada tingkat permintaan pelanggan. Permintaan mengalami kenaikan pada bulan tertentu, yaitu bulan Maret, Juli, dan September, serta penurunan pada bulan April dan Agustus pada tahun 2017 hingga tahun 2019. Pihak manajemen PT X telah menerapkan manajemen persediaan, yaitu dengan menentukan jumlah persediaan minimal yang harus disimpan perusahaan, atau yang dikenal sebagai persediaan pengaman. Namun, jumlah persediaan minimal tersebut ditentukan secara subjektif oleh kepala gudang tanpa memperhitungkan adanya lonjakan dan penurunan permintaan serta biaya persediaan yang ditimbulkan. Syarat yang ditentukan oleh Direktur Purchasing adalah memiliki persediaan pengaman yang cukup untuk mendukung proses produksi selama 2 bulan ke depan.

Sistem yang diterapkan pada perusahaan masih bersifat kekeluargaan dan konvensional, dilakukan dengan penilaian subjektif tanpa didasari dengan perhitungan yang tepat. Peramalan permintaan yang dilakukan oleh manajemen pun sifatnya subjektif dan berdasarkan pengalaman pada periodeperiode sebelumnya. Hal ini dapat menimbulkan biaya serta upaya tambahan apabila terjadi perubahan pada jajaran manajemen perusahaan, antara lain biaya dan waktu yang digunakan untuk pelatihan dan penyesuaian penerapan sistem perencanaan produksi yang baru. Faktor inilah yang menyebabkan terjadinya kekurangan dan kelebihan persediaan pada perusahaan di periode tertentu. Keputusan yang dilakukan pihak manajemen secara subjektif tidak dapat secara tepat mengantisipasi lonjakan maupun penurunan permintaan pelanggan. Manajemen belum pernah membentuk peramalan permintaan pelanggan yang dapat dijadikan alat bantu perusahaan dalam menghadapi fluktuasi permintaan.

Salah satu kendala yang ditemukan di perusahaan merupakan kendala tenaga kerja yang kemudian berdampak langsung dengan tingkat kecepatan dan kesiapan perusahaan dalam menghadapi fluktuasi permintaan pelanggan. Perusahaan perlu menerapkan sistem baru sebagai salah satu bentuk penyesuaian diri terhadap lingkungan internal maupun eksternal, yang dapat diawali dengan pembentukan dan penerapan perencanaan produksi serta pengendalian persediaan yang komprehensif. Dengan adanya sistem yang praktis, proses produksi menjadi lebih lancar dan perusahaan lebih produktif. Perusahaan juga dapat mengurangi biaya-biaya yang dapat dihemat melalui sistem perencanaan yang baik.

Bahan baku kasur per terdiri dari kawat, kain, busa, dan pita list. Disamping itu, terdapat pula beberapa bahan pembantu seperti staples elektrik, klem, serta ring untuk mengikat kawat dari jenis yang satu ke jenis yang lainnya. Dalam sebuah kasur per terdapat 2 komponen besar, yaitu rangka kasur dan kain, yang diilustrasikan pada Gambar 7. Bagian rangka kasur terbuat dari bahan baku kawat besi, yang kemudian diolah menjadi per serta rangka tulang kasur, sedangkan bagian kain penutup rangka terbuat dari lapisan spon dan kain yang dijahit menutupi rangka kasur menggunakan pita list. 
Gambar 4.1

Komponen Kasur PT X

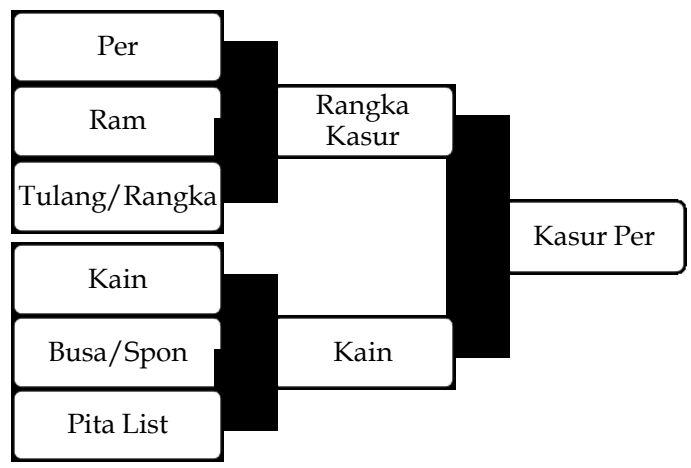

Sumber: Data Perusahaan, telah diolah kembali

Berdasarkan wawancara dengan Direktur Produksi PT $X$, perencanaan produksi perusahaan dilakukan setiap hari, melalui Kepala Bagian Produksi yang mendistribusikan perencanaan produksi kepada kepala bagian masing-masing departemen melalui formulir Surat Perintah Kerja (SPK). Peninjauan dan evaluasi target produksi dilakukan satu kali dalam satu tahun. Tiap divisi memiliki target produksi per hari sehingga apabila tingkat produksi tidak mencapai target, maka hal tersebut dapat tercermin pada laporan produksi tiap divisi untuk ditindaklanjuti.

Siklus pembelian bahan baku diawali dengan penghitungan kebutuhan bahan baku. Bahan baku utama yang dibutuhkan dalam proses produksi, misalnya kawat dan kain, dibeli melalui pemasok dari pulau Jawa, yaitu dari Jakarta, Surabaya, dan Bandung. Sebagai upaya agar perusahaan tidak mengalami stockout, maka pihak manajemen perusahaan menetapkan tingkat minimal stok bahan baku pada tingkat kebutuhan produksi perusahaan 2 hingga 3 bulan ke depan. Artinya, apabila stok bahan baku mencapai tingkat tersebut, maka bagian Purchasing perusahaan akan melakukan proses pemesanan. Hal ini dilakukan dengan mempertimbangkan waktu yang dibutuhkan perusahaan untuk memperoleh bahan baku tersebut.

Sistem pengendalian persediaan yang dilakukan perusahaan merupakan upaya perusahaan agar tidak kelebihan ataupun kekurangan persediaan. Kendati demikian, perusahaan mengalami setidaknya 1 hingga 2 kali kekurangan maupun kelebihan persediaan per tahun sehingga menghambat proses produksi. Penetapan sistem yang telah diimplementasikan pada perusahaan didasarkan pada pengalaman serta pengetahuan pihak manajemen mengenai tingkat permintaan pelanggan, tingkat kecepatan pemasok, maupun kapasitas penyimpanan bahan baku yang dimiliki perusahaan.

Proses pemesanan diawali dengan Purchase Request (PR) yang disetujui oleh Direktur Purchasing, kemudian diterbitkan Purchase Order (PO) untuk diteruskan pada pemasok. Para pemasok biasanya membutuhkan waktu beberapa hari untuk memproses pesanan. PT $X$ kemudian melakukan pemesanan jasa ekspedisi beserta kontener yang dibutuhkan untuk mengangkut barang tersebut. Pihak pemasok akan mengantarkan barang kepada perusahaan ekspedisi untuk dimuat pada kontener, kemudian diangkut ke pelabuhan untuk proses pengencekan dan pemuatan di kapal. Direktur Purchasing PT X, Bapak DD, mengatakan bahwa kendala yang biasanya ditemukan pada proses ini adalah dalam mencocokkan jadwal pemasok, ekspedisi, serta jadwal keberangkatan kapal, sehingga jadwal pengiriman barang dapat tertunda. Perjalanan kapal hingga sampai ke pelabuhan kota Makassar memakan waktu sekitar 1 minggu. Total waktu yang dibutuhkan sejak diterbitkannya PO hingga barang tiba di perusahaan berkisar antara 2 hingga 3 minggu.

Produk AMS merupakan produk yang mendominasi penjualan maupun tingkat produksi pada PT X, yaitu 40 hingga 50 persen dari total omzet perusahaan selama tahun 2017 hingga 2019. Menurut pihak manajemen PT X, hal ini disebabkan karena kedua produk tersebut merupakan produk pertama yang diluncurkan oleh perusahaan dengan kualitas yang cukup baik dan tahan lama dan ditawarkan dengan harga yang dapat diterima pasar. Produk kasur per yang diproduksi perusahaan mempunyai komponen bahan baku yang sama, namun terdapat beberapa 
kualifikasi berbeda seperti tingkat kepadatan spon, ukuran tulang rangka, serta ukuran per yang digunakan.

Sistem perencanaan produksi PT X untuk kedua produk ini akan dimulai dengan perhitungan peramalan permintaan produk. Data peramalan permintaan kemudian akan digunakan sebagai dasar perhitungan pada tahapan selanjutnya, yaitu penjadwalan induk produksi dan perencanaan kebutuhan sumber daya. Perencanaan produksi perlu didukung dengan adanya sistem manajemen persediaan yang baik. Sistem manajemen persediaan yang disarankan pada PT $X$ adalah dengan menghitung EOQ, persediaan pengaman, serta titik pemesanan kembali. Sistem tersebut akan mengatur pembelian bahan baku yang dibutuhkan oleh PT X agar tidak mengganggu alur produksi perusahaan.

\subsection{Peramalan PermintaAn}

Peramalan permintaan pelanggan terhadap produk AMS180 merupakan hitungan awal dalam pembentukan perencanaan produksi perusahaan. Metode yang digunakan dalam penelitian ini adalah metode moving average. Metode peramalan ini merupakan salah satu metode sederhana yang dapat digunakan untuk melakukan peramalan permintaan, khususnya permintaan yang memiliki pola yang sama tiap tahunnya. Permintaan pada PT X selama tahun 2017 hingga tahun 2019 menunjukkan adanya pola lonjakan pada bulan Maret, Juli, dan September. Melalui informasi dan data yang diperoleh dari perusahaan, bulan-bulan tersebut merupakan periode promosi, sehingga terdapat tren lonjakan musiman pada permintaan pelanggan. Berdasarkan data historis permintaan pelanggan selama tahun 2017 hingga 2019, diperoleh peramalan permintaan produk di tahun 2020 adalah sebagai berikut:
Tabel 4.1

Peramalan Permintaan Produk AMS180

\begin{tabular}{|l|r|r|r|r|}
\hline \multicolumn{1}{|c|}{ Bulan } & \multicolumn{1}{c|}{$\mathbf{2 0 1 7}$} & \multicolumn{1}{c|}{$\mathbf{2 0 1 8}$} & \multicolumn{1}{c|}{$\mathbf{2 0 1 9}$} & $\mathbf{2 0 2 0 ( f )}$ \\
\hline Januari & 1.406 & 1.462 & 1.535 & 1.468 \\
\hline Februari & 1.363 & 1.067 & 1.238 & 1.223 \\
\hline Maret & 1.855 & 1.712 & 2.055 & 1.874 \\
\hline April & 962 & 933 & 1.116 & 1.004 \\
\hline Mei & 1.368 & 1.590 & 1.382 & 1.447 \\
\hline Juni & 1.201 & 1.264 & 1.284 & 1.250 \\
\hline Juli & 1.709 & 1.983 & 1.881 & 1.858 \\
\hline Agustus & 1.087 & 1.326 & 1.418 & 1.277 \\
\hline September & 1.759 & 1.780 & 1.654 & 1.731 \\
\hline Oktober & 1.130 & 1.148 & 1.332 & 1.203 \\
\hline November & 1.363 & 1.256 & 1.269 & 1.296 \\
\hline Desember & 1.594 & 1.694 & 1.571 & 1.620 \\
\hline Total (buah) & $\mathbf{1 6 . 7 9 7}$ & $\mathbf{1 7 . 2 1 5}$ & $\mathbf{1 7 . 7 3 5}$ & $\mathbf{1 7 . 2 4 9}$ \\
\hline \hline
\end{tabular}

\subsection{JADWAL INDUK PRODUKSI}

Tahap selanjutnya dalam sistem perencanaan produksi PT $\mathrm{X}$ adalah dengan melakukan penjadwalan induk produksi. Tahap ini dilakukan dengan tujuan agar perusahaan memiliki pedoman dalam melakukan aktivitas produksi, yaitu dengan memproduksi barang sesuai dengan jadwal yang dibentuk dengan jumlah produksi yang telah ditentukan berdasarkan peramalan permintaan produk dengan mempertimbangkan kapasitas perusahaan.

Salah satu tahap yang dibutuhkan dalam membentuk penjadwalan induk produksi adalah dengan mengetahui Overall Equipment Effectiveness (OEE). OEE menunjukkan tingat efektivitas mesin yang digunakan dalam proses produksi, yang terdiri dari tiga penilaian, yaitu Availability, Performance, dan Quality. Hasil perhitungan OEE pada Tabel 4.2 menunjukkan tingkat efektivitas mesin berada pada kisaran $78 \%$ hingga $85 \%$. Angka OEE ini digunakan dalam upaya membentuk penjadwalan induk produksi, agar dapat dibentuk perencanaan yang realistis dan dapat digunakan secara praktis oleh perusahaan.

Lot Size merupakan jumlah produksi yang diharapkan dan diterapkan oleh perusahaan. 
Pada perencanaan produksi yang dibentuk, tingkat produksi dibagi menjadi 4 alternatif, yang dapat dilihat pada Tabel 2, yaitu 20\%, $50 \%$, $80 \%$, dan $100 \%$, yang bertujuan untuk mengantisipasi perubahaan permintaan pelanggan. Apabila tingkat permintaan menurun, misalnya pada bulan setelah periode promo, maka tingkat produksi diturunkan dengan kisaran $20 \%$ hingga $80 \%$. Penentuan tingkat produksi pada tahap berikutnya ditentukan berdasarkan perubahan permintaan serta jumlah persediaan awal produk tiap bulan.

Tabel 4.2

Lot Size Produk AMS180

\begin{tabular}{|c|c|c|c|c|}
\hline \multirow{2}{*}{ Produk } & \multicolumn{4}{|c|}{ Lot Size (buah) } \\
\cline { 2 - 5 } & $\mathbf{1 0 0 \%}$ & $\mathbf{8 0} \%$ & $\mathbf{5 0 \%}$ & $\mathbf{2 0} \%$ \\
\hline AMS 180 & 1.474 & 1.179 & 737 & 295 \\
\hline
\end{tabular}

Data peramalan permintaan pelanggan yang telah dijabarkan pada subbab sebelumnya digunakan dalam pembentukan perencanaan induk produksi. Hasil perencanaan induk produksi AMS180 dapat dilihat pada Lampiran 1. PT $X$ disarankan untuk memproduksi sebanyak total 17.392 buah AMS180 di tahun 2020. Hasil perencanaan induk produksi PT X membuktikan bahwa perusahaan memiliki kapasitas yang cukup untuk memenuhi permintaan pelanggan.

Penerapan perencanaan produksi secara subjektif yang selama ini dilakukan perusahaan belum dapat mengantisipasi lonjakan dan penurunan permintaan yang menyebabkan bertambahnya biaya, misalnya biaya tenaga kerja lembur dan harian. Tingkat produksi yang direncanakan telah memperhitungkan kapasitas penyimpanan barang jadi PT $X$ sehingga jumlah produk yang disimpan masih dalam batas yang dapat ditampung oleh perusahaan. Hal ini menunjukkan apabila data peramalan tepat, maka perusahaan dapat melakukan penghematan khususnya dalam bentuk pengurangan upah lembur dan upah tenaga kerja harian apabila terdapat lonjakan permintaan pelanggan.

\subsection{Pengendalian PersediaAn}

Salah satu tujuan pengendalian persediaan adalah agar perusahaan dapat menekan biaya yang ditimbulkan dari persediaan, misalnya biaya yang dikeluarkan perusahaan untuk menyimpan persediaan atau yang dikenal sebagai carrying cost, maupun biaya pemesanan barang, yang dilakukan dengan menghitung jumlah pemesanan optimal, dan titik pemesanan kembali yang harus dilakukan oleh perusahaan. Selain itu, agar alur produksi dapat berjalan lancar, perusahaan membutuhkan adanya persediaan pengaman yang dapat digunakan sebagai antisipasi apabila terjadi keterlambatan dalam pengiriman, maupun fluktuasi permintaan yang sangat signifikan, sebagai cadangan persediaan perusahaan.

Carrying cost PT $\mathrm{X}$ berada pada rata-rata 8,08\%, yang dapat dilihat pada Tabel 4.3. Artinya, biaya yang muncul akibat penyimpanan persediaan pada PT $X$ adalah sebesar $8,08 \%$ dari total persediaan yang dimiliki perusahaan. Biaya tersebut berupa pemeliharaan mesin, perbaikan gedung, penyusutan bangunan, serta penyusutan mesin.

Tabel 4.3 Carrying Cost PT X

\begin{tabular}{|c|c|c|c|}
\hline & 2017 & 2018 & 2019 \\
\hline Mesin & 506.172 & 533.294 & 599.044 \\
\hline Perbaikan Gedung & 42.282 & 54.353 & 85.911 \\
\hline Penyusutan Bangunan & 144.150 & 144.076 & 124.659 \\
\hline \multirow[t]{2}{*}{ Penyusutan Mesin } & 354.104 & 352.318 & 408.826 \\
\hline & Rp 1.046 .708 & $\operatorname{Rp} 1.084 .042$ & $\operatorname{Rp} 1.218 .440$ \\
\hline Persediaan & Rp 11.895.427 & Rp 13.723.881 & Rp 16.123.982 \\
\hline Carrying Cost & $8,80 \%$ & $7,90 \%$ & $7,56 \%$ \\
\hline Rata-Rata & \multicolumn{3}{|c|}{$8,08 \%$} \\
\hline
\end{tabular}


Sistem pengendalian persediaan yang disarankan untuk PT X diproyeksikan dalam tiga skenario: skenario normal, optimis, dan pesimis. Hal ini dilakukan agar perusahaan memiliki alternatif dalam memilih strategi yang digunakan. Apabila manajemen optimis, maka diasumsikan bahwa tingkat permintaan adalah sebesar 115\%. Namun apabila manajemen pesimis, maka diasumsikan tingkat permintaan adalah sebesar $85 \%$. Skenario ini dapat dilihat pada Tabel 4.4, yaitu perhitungan untuk bahan baku K02.

EOQ menunjukkan jumlah optimal pemesanan bahan baku dalam satu kali pemesanan, misalnya jumlah kawat K02 adalah sebanyak 20.985 kilogram, atau 20,9 ton. Artinya, pada tingkat pemesanan tersebut, biaya persediaan mencapai titik paling optimal, dimana biaya pemesanan perusahaan sama dengan carrying cost. Angka tersebut dihasilkan dengan mempertimbangkan biaya pemesanan, biaya penyimpanan, serta tingkat kebutuhan rata-rata perusahaan dalam setahun. Pada Tabel 4.4 dapat dilihat bahwa apabila tingkat permintaan normal (100\%), maka tingkat optimal pemesanan $\mathrm{K} 02$ adalah sebanyak 20.985 kilogram. Namun apabila tingkat permintaan pesimis $(85 \%)$, maka terdapat penurunan permintaan dan kenaikan pada biaya pemesanan dan carrying cost, sehingga tingkat optimal pemesanan menjadi 18.881 kilogram dalam sekali pemesanan.

Persediaan pengaman merupakan standar atau batas bawah toleransi perusahaan untuk tingkat persediaan bahan baku. Jumlah persediaan yang dimiliki perusahaan sebaiknya tidak lebih kecil dari jumlah persediaan pengaman yang ditentukan. Selama ini perusahaan belum menentukan titik yang jelas antara persediaan pengaman dan titik pemesanan kembali. Pihak manajemen menentukan bahwa tingkat persediaan pengaman merupakan titik pemesanan kembali, dimana apabila persediaan mulai berkurang dan dinilai tidak dapat mencukupi kebutuhan produksi selama dua hingga tiga bulan ke depan, maka perusahaan harus mulai merencanakan pembelian bahan baku. Perusahaan membutuhkan waktu rata-rata 5 hingga 25 hari sejak pemesanan barang hingga barang diterima oleh pihak gudang. Hal ini perlu diantisipasi dengan ditentukannya titik pemesanan bahan baku yang digunakan perusahaan agar tidak mengganggu alur produksi.

Tabel 4.4 Perhitungan EOQ Bahan Baku AMS180

\begin{tabular}{|c|c|c|c|}
\hline & $\begin{array}{c}100 \% \\
\text { Normal } \\
\end{array}$ & $\begin{array}{c}115 \% \\
\text { Optimis }\end{array}$ & $\begin{array}{c}85 \% \\
\text { Pesimis }\end{array}$ \\
\hline Proyeksi Produksi AMS180 & 17.392 & 20.001 & 14.783 \\
\hline $\begin{array}{l}\text { Kebutuhan Bahan Baku } \\
\text { K02 (kg) }\end{array}$ & & & \\
\hline Unit Cost / kg $\quad \mathrm{Rp} 11.818$ & $030.0<0$ & 400.210 & 290.029 \\
\hline Biaya Pemesanan $\quad$ Rp 600.000 & & & \\
\hline Total Biaya Pemesanan & Rp10.025.167 & Rp10.478.578 & Rp 9.470.997 \\
\hline Carrying Cost & $8,08 \%$ & $7,68 \%$ & $8,49 \%$ \\
\hline Total Carrying Cost & Rp10.025.167 & Rp $\quad 10.478 .578$ & 9.470 .997 \\
\hline EOQ (kg) & 20.985 & 23.088 & 18.881 \\
\hline
\end{tabular}

Tabel 4.5 menjabarkan perhitungan persediaan pengaman dan titik pemesanan kembali bahan baku K02, yang juga dituangkan menjadi tiga skenario: normal, optimis, dan pesimis. Pada kondisi optimis diasumsikan bahwa lead time pembelian bahan baku 15\% lebih cepat dari kondisi normal dengan tingkat penggunaan $10 \%$ lebih tinggi dari kondisi normal. Berdasarkan ketiga skenario tersebut, maka terdapat 3 skenario persediaan pengaman dan titik pemesanan kembali. Hal ini dilakukan untuk memberikan alternatif pada strategi yang digunakan perusahaan dalam mengambil keputusan. Apabila 
perusahaan optimis bahwa bahan baku dapat diterima lebih cepat dari normal namun tingkat permintaan pun menurun, maka perusahaan dapat memilih skenario 3, dimana persediaan pengaman berada pada titik terendah, yaitu 17.733 kilogram.

Tabel pengendalian persediaan diatas diolah menggunakan data PT X tahun 2017 hingga 2019, antara lain data rata-rata serta lead time serta penggunaan harian bahan baku yang digunakan perusahaan, biaya penanganan persediaan, serta jumlah bahan baku yang dipesan perusahaan dalam satu pemesanan. Metode ini dapat memberikan standar bagi perusahaan, terutama pada bagian gudang

Tabel 4. 5 Perhitungan Persediaan Pengaman K02

\begin{tabular}{|l|r|r|r|}
\hline Bahan Baku K02 & $\mathbf{1 0 0 \%}$ & $\mathbf{1 1 0 \%}$ & $\mathbf{8 5 \%}$ \\
\hline $\begin{array}{l}\text { Lead Time } \\
\text { Rata-Rata (hari) } \\
\text { Penggunaan per hari* } \\
\text { Rata-Rata (kg) }\end{array}$ & 21 & 18 & 23 \\
\hline \multicolumn{3}{|c|}{ Persediaan Pengaman (kg) } \\
\hline Skenario 1 & 24.544 & 20.862 & 26.998 \\
Skenario 2 & 28.225 & 23.991 & 31.048 \\
Skenario 3 & 20.862 & 17.733 & 22.948 \\
\hline \multicolumn{4}{|c|}{ Titik Pemesanan Kembali (kg) } \\
\hline Skenario 1 & 48.684 & 44.485 & 49.536 \\
Skenario 2 & 52.335 & 47.588 & 53.552 \\
Skenario 3 & 45.032 & 41.381 & 45.519 \\
\hline \multicolumn{4}{|c|}{ *satu tahun = 300 hari kerja }
\end{tabular}

serta pembelian, dalam menentukan tingkat persediaan perusahaan. Metode yang selama ini digunakan perusahaan bergantung pada individu tertentu, sehingga apabila terjadi pergantian jajaran manajemen, akan dibutuhkan waktu serta biaya dalam trial and error dalam penerapan perencanaan produksi maupun manajemen persediaan PT X.

\section{SIMPULAN}

Permasalahan persediaan yang dihadapi perusahaan diakibatkan oleh perencanaan produksi yang kurang tepat. Perusahaan mengalami kelebihan serta kekurangan persediaan khususnya pada periode promosi, sehingga kapasitas produksi perusahaan dinilai tidak dapat mencukupi permintaaan pelanggan yang melonjak. Solusi yang selama ini diterapkan PT $X$ adalah dengan mempekerjakan tenaga kerja lembur dan tenaga kerja lepas guna meningkatkan tingkat produksi perusahaan. Solusi ini dapat mengantisipasi pesanan yang meningkat, namun dapat menyebabkan adanya penumpukan persediaan pada periode nonpromosi. Penumpukan persediaan dapat meningkatkan biaya persediaan, yang akhirnya dapat berdampak secara tidak langsung pada laba perusahaan. Permasalahan tersebut belum dapat diatasi oleh perusahaan hingga saat ini.

Salah satu faktor yang menyebabkan adanya permasalahan persediaan adalah sistem perusahaan yang masih bersifat konservatif dan kekeluargaan. Jajaran manajemen perusahaan belum pernah mengalami perubahan selama 10 tahun terakhir, sehingga perusahaan tidak bergerak secara dinamis mengikuti perkembangan zaman. Sistem perencanaan produksi serta pengendalian persediaan yang diterapkan pada perusahaan bersifat subjektif, tanpa didasari perhitungan yang tepat. Perusahaan belum pernah menerapkan perencanaan produksi yang komprehensif berdasarkan peramalan permintaan pelanggan. Sistem pada perusahaan didasarkan pada pengetahuan dan pengalaman jajaran manajemen dalam menghadapi volatilitas permintaan dan pengaturan alur produksi. Manajemen PT X memiliki kendali penuh atas penentuan jumlah produksi perusahaan berdasarkan penilaian subjektif dan kesigapan manajemen dalam menghadapi permintaan pasar. Ketergantungan sistem ini pada pihak tertentu dapat menyebabkan ketidaksiapan perusahaan apabila terjadi pergantian pada jajaran manajemen.

Upaya yang dapat dilakukan perusahaan untuk mengantisipasi hal tersebut adalah dengan membentuk suatu perencanaan yang komprehensif, baik perencanaan produksi maupun sistem pengendalian persediaan. Sistem pengendalian persediaan diperlukan untuk mendukung proses produksi dengan memperhitungkan lead time, sehingga dapat mengantisipasi terjadinya kekurangan bahan baku yang dapat mengganggu proses produksi 
perusahaan. Perencanaan produksi yang dibentuk dalam penelitian ini diawali dengan peramalan permintaan, pembentukan jadwal induk produksi, serta perencanaan kebutuhan sumber daya. Sedangkan sistem pengendalian persediaan yang disarankan bagi perusahaan adalah dengan menggunakan EOQ, Persediaan Pengaman, serta Titik Pemesanan Kembali. Pemilihan metode ini mempertimbangan kebutuhan perusahaan serta kesiapan dan kemampuan tenaga kerja yang ada pada PT X.

Dengan adanya perencanaan produksi yang baik diharapkan perusahaan dapat mengantisipasi fluktuasi permintaan pelanggan, yang dilakukan berdasarkan peramalan permintaan dengan data historis perusahaan. Selain itu, perusahaan juga dapat mengurangi biaya tenaga kerja lembur, karena kapasitas perusahaan dapat memenuhi permintaan pelanggan yang diramalkan. Perusahaan dapat mengalokasikan biaya tersebut pada pengembangan produk, kualitas produk, sistem, dan sebagainya. Pengurangan lead time yang digunakan untuk mendistribusikan perencanaan produksi pada tiap divisi pun dapat dipersingkat dengan adanya perencanaan ini. Sistem yang disarankan dapat mempersiapkan perusahaan apabila terjadi pergantian jajaran manajemen sehingga perusahaan tidak lagi bergantung pada individu tertentu dalam menentukan produk, kapan dan berapa jumlah yang harus di produksi. Implementasi sistem ini dapat menyediakan ruang bagi perusahaan dan menjadi titik awal bagi perusahaan untuk melakukan pengembangan, baik dalam bentuk sistem maupun inovasi produk.

Keterbatasan penelitian ini terdapat pada objek penelitian, yaitu perusahaan pada industri manufaktur kasur per yang terletak di kota Makassar. Selain itu, metode yang digunakan dalam pembentukan perencanaan produksi dan manajemen persediaan pun terbatas, disesuaikan dengan kondisi dan kemampuan perusahaan.

Berdasarkan keterbatasan penelitian di atas, maka saran yang dapat diberikan pada penelitian selanjutnya antara lain pemilihan objek penelitian yang beragam serta penggunaan metode dan teori manajemen produksi dan persediaan lain, tidak terbatas pada penelitian ini.

\section{REFERENSI}

Akande, O. (2019). An Integrated Approach To Production Planning And Control Systems In Small Scale Industry. ProQuest LLC.

Barwa, T. M. (2015). Inventory Control as an Effective Decision-Making Model and Implementations for Company's Growth. International Journal of Economics, Finance and Management Sciences, 3(5), 465. https://doi.org/10.11648/j.ijefm.2015030 5.18

Bastian, I., Winardi, R. D., \& Fatmawati, D. (2018). Metoda Wawancara. Metoda Pengumpulan Dan Teknik Analisis Data, (September 2018), 53-99.

Chan, F. T. S., \& Prakash, A. (2012). Inventory management in a lateral collaborative manufacturing supply chain : a simulation study, 50(16), 4670-4685. https://doi.org/10.1080/00207543.2011.6 28709

Chinguwa, S., Madanhire, I., \& Musoma, T. (2013). A Decision Framework based on Aggregate Production Planning Strategies in a Multi Product Factory: A Furniture Industry Case Study. International Journal of Scientific Engineering and Research (IJSER), 1(1-3). Retrieved from www.ijser.in

Fajar, M., \& Lestari, Y. D. (2017). Aggregate Planning Analysis in PT. Akebono Brake Astra. Journal of Business and Management, 6(2), 182-191.

Gimenez, C., \& Ventura, E. (2005). LogisticsProduction, Logistics-Marketing and External Integration: Their Impact on Performance. International Journal of Operations and Production Management, (February).

Rădăşanu, Ａ. C. (2016). Inventory Management, Service Level and Safety Stock. Journal of Public Administration, 
Finance and Law, (09), 145-153.

Shenoy, D., \& Rosas, R. (2018). Problems \& Solutions in Inventory Management. Springer. https://doi.org/10.1007/978-3319-65696-0_1

Silver, E. A., Pyke, D. F., \& Peterson, R. (2016). Inventory and Production Management in Supply Chains (4th ed.). CRC Press.

Sporta, F. O. (2018). Effect of Inventory Control Techniques on Organization's Performance at Kenya Medical Supplies Agencies. The International Journal of Business E Management, 6(3).
Thompson, A. A., Gamble, J. E., Peteraf, M. A., \& Strickland III, A. J. (2018). Crafting $\mathcal{E}$ Executing Strategy - The Quest for Competitive Advantage. New York: McGraw-Hill Education.

Vincent, O., Ijedinma, N. O., \& Onyemachi, U. C. (2018). Production Planning and Organizational Effectiveness. Strategic Journal of Business and Social Science, 1, 128. 